УAK [005.521:32]:324

ББК $66.06+66.3(0), 131$

DOI 10.22394/1682-2358-2020-1-97-102

K.D. Kurgacheva, postgraduate student of the Philosophy and Politics Department, Basbkir State University

\section{BLACK PR}

\section{AS A FUNCTION}

OF THE POLITICAL

INTERNET

\section{(Case Study of Russian Election Campaigns)}

The problem of network manipulative technologies in politics and their influence on the electorate consciousness during the election campaign is considered. The analysis of using black PR as one of the functions of political Internet in Russia is carried out. Discrepancies between potential possibilities of black PR and domestic practice are revealed, theoretical substantiations to this phenomenon are given.

Key words and word-combinations: political Internet, black PR, mind manipulation, Internet resources.
K.А. КургачеВа, аспирант кафедро философии и политологии Башкирского государственного университета

(email: kurgachevakristi@mail.ru)

\section{ЧЕРНЫЙ ПИАР \\ КАК ФУНКЦИЯ \\ ПОАИТИЧЕСКОГО ИНТЕРНЕТА \\ (на примере российских \\ избиратемьных кампаний)}

\begin{abstract}
Аннотайя. Рассматривается проблема сетевых манипулятивных технологий в политике и выявляется их воздействие на сознание электората в период избирательной кампании. Анализируется использование черного пиара как одной из функций политического Интернета в России. Выявлены несоответствия между потенциальными возможностями черного пиара и отечественной практикой, приводятся теоретические обоснования изучаемого явления.

Ключевые слова и словосочетания: политический Интернет, черный пиар, манипуляция сознанием, интернет-ресурсы.
\end{abstract}

K становится широкая информатизация процессов и явлений соџиальной действительности, которая вцечет за собой трансформацию традиџионных соџиальных установок. В этих условиях одной из ключевых технологий, неразрывно связанной с развитием инновационных каналов соџиальной коммуникации и взаимодействия явмяется Интернет, на технической базе которого формируется гмобальное информационно-коммуникационное пространство современности. 
Сетевые технологии превратились в атрибуты подавляющего большинства соџиальных практик, сохранивших свою актуальность в рамках посттрадиџионного общества.Среди подобных непреходящих звеньев системы соџиальных отношений, подвергшихся воздействию информатизаџии, особого внимания заслуживает сфера «политического», неразрывно связанная с проблемой власти и способами ее удержания. В результате этого значительный пласт информационных потоков глобальной Сети преАставлен контентом политического характера. Роль подобной информации в системе соџиального взаимодействия настолько велика, что очевидна џелесообразность выделения политического Интернета, в рамках которого возможен полноценный анализ политического онлайн-взаимодействия.

В отечественной политологической мысли категория политического Интернета наиболее детально была разработана в работах Н.В. Солениковой, опредемяющей политический Интернет как «новейшую эмектронно-компьютерную разновидность средства массовой коммуникации в сфере политико-властных отношений, созданную на основе принщипа обратной связи и явАяюшуюся как виртуальным пространством Аля быстрых и разнонаправленных потоков политической информации и коммуникации, так и современным ресурсом и технологией политического влияния, завоевания доверия и поддержки общественности, политического участия и политической борьбы, что существенно влияет на характер актуального политического общения, качественно меняет язык политического дискурса и стилистику политической конкуренции» [1,с. 31]. По нашему мнению, политический Интернет не преАставцяет собой обособленный сегмент Сети. Напротив, он вбирает в себя все ее ресурсные и функциональные возможности, а условная граница между политическим Интернетом и глобальной Сетью заключается исключительно в характере контента.

В условиях, когда информация, загруженная в Сеть, превращается в один из самых эффективных ресурсов воздействия на сознание соџиального субъекта, в поведении политических акторов ярко проступают черты макиавемлизма и наблюдается умелый, пусть и не всегда афишируемый отход от идеализированных моделей социального взаимодействия, изложенных, например, в работах С. Бцэка, который, анализируя пиар (PR), писал, что это «искусство и наука достижения гармонии между политической элитой и общественностью с помощью взаимопонимания, основанного на правде и полной информированности» [2]. На практике как в России, так и за рубежом, подобные утопические модели оказываются маложизнеспособными. Они могут быть рассмотрены исключительно как недостижимый во всей полноте идеал, к которому необходимо стремиться в целях совершенствования политической системы, но оАновременно осознавать его практическую неосушествимость.

Представмяется необходимым детально рассмотреть сетевые манипулятивные технологии воздействия на массы, осуществмяемые в период избирательной кампании. Аанный выбор обусловлен тем, что в демократических государствах роль функџиональных и ресурсных возможностей политического Интернета наиболее ярко проявцяется во время выборов. Именно в этот период ценность информаџионного обмена межАу насемением и политическими акторами достигает максимальных значений, так как эффективный контакт с 
электоратом явмяется необходимым условием Аля достижкения и удержкания власти. Особое внимание уделим пиару, а именно такой его разновидности, как черный пиар. Рассмотренная как одна из функций политического Интернета, черная пиар-кампания во многом детерминирует образ политического актора в глазах социального субъекта и в результате влияет на итог голосования.

В условиях альтернативных и конкурентных выборов технология черного пиара применима в качестве одного из универсальных политических инструментов «грязных» технологий, Аающих неоспоримые преимущества переА конкурентами. Среди отечественных исследователей, изучающих специфику применения черного пиара в рамках избирательного процесса, отметим П.С. Камчатную и М.С. Савенкова, которые полагают, что «черный пиар - это целенаправленная деятельность, имеющая целью разрушение или ухудшение имиджа конкретного мица или организации» [3, с. 50]. Аналогичную позицию разделяют Ю.А. Вамитова, В.В. Аебенкова [4], А.С. Обычайко, Б.Ц. Овцыкови Аругие ученые [5] . Наиболее ярко данная политическая технология используется во время избирательной гонки, когда межпартийная борьба за сознание электората особо обострена. Применяя «некорректные» приемы и методы, участники электорального проџесса могут не только повлиять на итоги выборов, но и осуществить манипуляционные воздействия на потенциальных избирателей.

Сегодня одним из наиболее распространенных приемов черного пиара, применяемых в рамках избирательного проџесса, является подача заведомо можной информации о кандидате. В рамках политического Интернета подобная технология реализуется в несколько этапов.

Во-первых, необходимо провести предварительную генерацию и отборкомпрометирующей информации, которая вкцючает как реальные факты об оппоненте, так и сведения, не соответствующие Аействительности, но внешне похожие на нее до такой степени, что делает их реальными в глазах потенциацьного электората.

Во-вторых, производится вброс сформированной информации непосредственно в Сеть. Необходимо учитывать основные интернет-тренды, актуальные на момент вброса, которые вкцючают в себя особые формы подачи визуальной, текстовой и звуковой информации, популярные в Аанный период среди пользователей Сети. Необходим грамотный выбор каналов трансляџии информации, особую роль среди которых играют соџиальные сети как кмючевые коммуникационноинформационные площадки Интернета, а также мессенджеры и YouTube.

Второй этап реализации данной технологии явцяется, на наш взгляА, более трудоемким, чем первый. Существование политического Интернета приводит к возникновению новых динамичных каналов коммуникации и социального взаимодействия, в рамках которых кцассические технологии поиска и вброса компрометирующей информации не всегда эффективны. Работа по вбросу информации в Интернет требует креативного и творческого подхода, что усможняет Аанную технологию дия большинства отечественных политических сил, которые характеризуются определенным консерватизмом.

Тем не менее в отечественных электоральных кампаниях наглядные примеры использования технологий черного пиара реацизованы на базе политического Интернета. ОАним из наглядных примеров использования данной 
технологии служит инџидент, произошедший в г. Ирбит Свердиовской области в сентябре 2016 г. в предаверии выборов в Государственную Ауму РФ.

В соџиальной сети «Аруг Вокруг» произошла массовая рассылка сообщений от имени партии $\Lambda \Lambda$ ПР со следующим содержанием: «ЗАравствуйте, вас приветствует избирательная партия $\Lambda, \Lambda$ ! В связи с выборами, которые состоятся 18.09.2016 г. партия $\Lambda \Lambda$ ПР преАлагает помощь населению в денежной поддержке в размере 3000 т.р., дмя получения выплаты вам нужна карта Сбербанк с мобильным банком, если вам нужна помощь, то пишите нам, спасибо, ваша партия $\Lambda \Lambda$ ПР» [6]. Вскоре на офиџиальных ресурсах партии появикась опровергающая Аанный вброс информация [7]. В частности, разъяснялось, что согласно российскому законодательству подобная деятельность явцяется правонарушением. Этот вброс как практическая реацизаџия техномогии черного пиара был реализован с применением интернет-технологий и направлен на очернение имиджа политической партии в условиях электоральной кампании федерамьного уровня.

Еще один пример черного пиара можно привести из хода президентской избирательной кампании 2018 г., когда от миџа П.Н. Грудинина, выдвинутого партией КПРФ на Аолжность Президента РФ, произошла спам-рассылка электронных писем в аАрес крупных торговых точек Москвы с требованием выплатить две тысячи домларов. При условии отказа от уплаты денежной суммы анонимные пользователи угрожали их владельцам [8]. В данной ситуации использовалась можная информация о кандидате в целях негативной окраски политического актора в глазах эмектората.

Приведенные примеры черной пиар-деятельности не стали широко известны публике и не оказали значительного эффекта на ход избиратемьных кампаний. Вероятно, это произошло вследствие недостаточно продуманных способов трансляции информации - использования электронной почты и мамоизвестной соџиальной сети, что слелало данные вбросы камерными и, как следствие, малоэффективными. Кроме того, их содержание включало в себя информацию, явно нарушающую российское законодательство, и не похожую на реальность до такой степени, что большинство объектов воздействия восприняли ее как изначально фейковую.

В современной российской практике сложилась ситуация, когда наиболее активными и умелыми пользователями политического Интернета явцяются так называемые несистемные политики, максимальную известность среди которых приобрел А.А. Навальный, который явмяется активным пользователем YouTube, Twitter, Вконтакте и Аругих социальных сетей. Например, с его именем связано распространение в Интернете информации от ииџа предсеАателя ЦИК РФ Э.А. Памфимовой, где населению преАлагалось проголосовать за В.В. Путина. В ряде сообщений было написано, что «бюджетные Аеньги мы потратили на приумножение богатств В.В. Путина, а не на нормальные дороги и больниџы» [9]. Агитация по распространению подобной информации была реализована на страничке оппозиционного политика в Twitter. Аействия А.А. Навального стали своеобразным ответом на скандац, произошеАший накануне выборов Президента России 2018 г.,когАа ЦИК отказала ему 
в регистрации в качестве кандидата на пост главы государства [10]. В ответ на развернутую черную пиар-кампанию, направленную в аАрес В.В. Путина и Э.А. Памфиловой, где использовался политический ярлык «вор» в значении «мошенник», ЦИК выступила с опровергающим заявлением о распространении недостоверной информаџии в Интернете.

Аанный инџидент наглядно демонстрирует пример применения черных пиар-технологий, реализованных на базе политического Интернета в российском политическом пространстве. Речь идет не только о приеме вброса ложной информации о политическом милере, но и о технологии навешивании ярлыков, которая заключается в умышиенной дискредитации оппонента, позволяющей манипулировать общественным мнением. Ярлыки, транслируемые при помощи Интернета, представцяют собойлингвистические номинации, «не требующие от аудитории какой-либо интерпретации, но преАлагающие готовое решение, определенную формулу, обладающую высокой степенью устойчивости и удобную Аля Аальнейшего тиражирования» [11, с. 76]. Метод наклеивания ярлыков преАставляет собой одну из наиболее эффективных технологий черного пиара в условиях российской политической действительности, что нагляАно Аемонстрируется еще одним известным информационным вбросом А.А. Навального.

В 2011 г.в интервью информационному каналу «Сухой остаток» на Финам FMA. А. Навальный отмечал: «Партия "ЕАиная Россия” - это партия коррупции, это партия жкуликов и воров» [12]. Несмотря на то что похожие формумировки произносились и ранее, например В.В. Жириновским [13] и Б.Е. Немџовым [14], именно А.А. Навальный популяризировал данное утверждение Ао такой степени, что оно впоследствии превратилось в один из наиболее известных политических интернет-мемов Рунета. Оценочное высказывание в аАрес правящей партии сопровождается эмоџионально окрашенными словами «жумики», «воры» в значении - обманщики, коррупџионеры, играющими роль ярмыков, направленных на подрыв авторитета политической партии и ее мидера.

Несмотря на широкий обшественный резонанс и массовое использование Аанного ярлыка, как в российском политическом Интернете, так и в офмайнпространстве рейтинг партии «ЕАиная Россия» по-прежкнему занимает кидирующие позиции. Это дает основание полагать, что, хотя черные пиар-акции реализованы на базе политического Интернета,онив значительной степени воздействуют на сознание электората, формируя политическое информационное пространство Сети, что особенно ярко видно по деятельности несистемных политических сил, которые активно используют функщионал Сети. В условиях российской политической действительности наблюдается опредеменный «застой» на уровне федеральных политических сил.

Опираясь на консервативную часть населения, основным источником информации которой явмяются кмассические СМИ, крупнейшие из которых напрямую принадлежат государству, а также на административный ресурс, федеральная политическая система, на наш взгляА, имеет тенденцию к косности и оторванности от настроений масс. Это задает определенные риски Аця будущего политической системы, которое неизбежно связано с сетевыми технологиями. 
Таким образом, черный пиар явмяется одной из ключевых функций современного политического Интернета, наибольшая актуальность которого проявмяется в условиях электоральной кампании. Несмотря на высокий потенциал черного пиара в борьбе за массовое сознание, в отечественной политической практике значительный вес имеют консервативные тенденции и шаблонный подход к реализации сетевых технологий, что приводит к минимизации эффекта от черного пиара. Исключением явмяется деятельность несистемной оппозиџии, активно использующей Сеть в своей практике и умеющей креативно подавать контент, в результате чего ее месседжи активно принимаются и транслируются пользователями Интернета, способствуя формированию оппозиџионного и протестного сетевого пространства. В рамках грядущего эмекторального цикма политические акторы, в особенности несистемная оппозиџия, продолжат наращивать использование черного пиара и интернет-технологий, так как перенос в Сеть основных информаџионных потоков вынуждает даже самых консервативных игроков активно использовать Интернет. Сиедовательно, на государственном уровне необходимо проработать законодательные механизмы защиты от черного пиара, четко фиксирующие правовую ответственность за распространение порочащей информаџии в Сети.

\section{Библиографический список}

1. Соленикова Н.B. Политический интернет в российских избирательных кампаниях: тенденции и проблемы развития: дис. ... канд. полит.наук. Уфа, 2007.

2. Блэк С. Паблик рилейшнз. Что это такое? URL: http://mreadz.com/read-202822

3. Камчатная П.С., Савенкова М.С. Использование черного PR в международной политике // Тенденции развития науки и образования. 2018. № 44-4. С. 50-54.

4. Валитова Ю.Д. Негативные методы воздействия с помощью PR // Интегрированные коммуникации в спорте и туризме: образование, тенденции, международный опыт. 2017. Т. 1. С. 40-44.

5. Лебенкова В.В., Обычайко А.С., Овльыков Б.Ц. Анти-пиар как метод «черных технологий» // Социально-гуманитарные проблемы образования и профессиональной самореализации // Социальный инженер-2016: сборник материалов Всероссийского научного форума молодых исследователей. М., 2016. С. 45-47.

6. Мошенники предлагают деньги жителям Ирбита от имени ЛДПР. URL: https://www. znak.com/2016-08-10/moshenniki_predlagayut_dengi_zhitelyam_irbita_ot_imeni_ldpr

7. Активисты ЛДПР выявили мошенников! // Официальная страница партии ЛДПР Вконтакте.URL: https://vk.com/liberal_democratic_party

8. Полиция проверяет информацию орассылкеписем с угрозами от «Грудинина».URL:http://2017. vybor-naroda.org/lentanovostey/108393-policiya-proveryaet-informaciyu-o-rassylke-pisem-s-ugro

9. В ЦИК открестились от листовок о безальтернативных выборах президента. Навальный: «Огорчайте ЦИК!». URL: http://2017.vybor-naroda.org/lentanovostey/107201-v-cik-otkrestilis-ot-listovok-o-bezalternativnyh-vyborah-prezidenta-navalnyy-ogorchayte-cik.html

10. ЦИК отказал Навальному в регистрации кандидатом в президенты. URL: https://www. gazeta.ru/politics/news/2017/12/25/n_10979222.shtml

11. Кузьминская С.И. «Ярлык» как средство манипулирования массовым сознанием // В мире науки и искусства: вопросы филологии, искусствоведения и культурологи. 2004. № 36. С. 75-80.

12. Финам FM. Архив программы «Сухой остаток» от 2 февр. 2011 г.: видеозапись интервью с Навальным.URL: https://www.youtube.com/watch?v=leHWbcmd74E

13. В круге света: Миграция - «Эхо Москвы».2013. 27 авг. URL: https://echo.msk.ru/programs/s

14. Политик Борис Немцов - об отставке мэра Москвы. URL: https://www.svoboda.org/a/2170127 